\title{
Abundance of pathogenic bacteria and viral indicators in chlorinated effluents produced by four wastewater treatment plants in the Gauteng Province, South Africa
}

\author{
M Dungeni', RR van der Merwe ${ }^{2}$ and MNB Momba ${ }^{1 *}$ \\ ${ }^{1}$ Department of Environmental Water and Earth Sciences \\ ${ }^{2}$ Department of Food and Biotechnology, Tshwane University of Technology, Arcadia Campus, Private Bag X680, Pretoria 0001, South Africa
}

\begin{abstract}
The failure of South African wastewater treatment plants to produce effluents of a high microbiological quality is a matter of great concern in terms of the pollution of water resources. This study aimed at assessing the effectiveness of 4 wastewater treatment plants in the Gauteng Province, namely the Zeekoegat, Baviaanspoort, Rayton and Refilwe Water Care Works (WCW), in the removal of pathogenic bacteria and viral indicators. Also taken into consideration were free chlorine concentrations and turbidity levels, which were measured using standard methods. Conventional methods and/or polymerase chain reaction (PCR) techniques were used to detect and identify pathogenic bacteria and coliphages. The turbidity ranged from 2.39 to $62.40 \mathrm{NTU}$ and the concentrations of free chlorine ranged from 0.03 tol.60 mg $\ell^{-1}$ for all plants. Despite high free chlorine residual concentrations in treated effluents, the survival and occurrence of Escherichia coli, Salmonella typhimurium and Vibrio cholerae were significantly higher at Baviaanspoort $(100 \%, 88.2 \%$ and $35.3 \%)$, Refilwe $(87.5 \%, 59.4 \%$ and $21.9 \%)$ and Rayton $(75 \%, 38.2 \%$ and $9.4 \%)$ compared to Zeekoegat, which only showed the survival of $E$. coli, at a much lower occurrence rate of $8.8 \%$. Somatic and F-RNA coliphages were removed at $15.57 \%$ and $13.96 \%$ for Baviaanspoort, $11.62 \%$ and $22.42 \%$ for Refilwe, $25 \%$ and $32.10 \%$ for Rayton, and $40.41 \%$ and $52.57 \%$ for Zeekoegat WCW. Significant correlations were found between pathogenic bacteria and coliphages at all plants $(r=0.765$ for Baviaanspoort, $r=0.904$ for Zeekoegat, $r=0.680$ for Refilwe, $r=0.796$ or the Rayton WCW, $p<0.01$ ). A combination of sedimentation, rapid sand filtration and chlorination processes was found to be a major prerequisite for the reduction of turbidity levels and viral indicators and the successful removal of pathogenic bacteria in the Zeekoegat WCW. This study therefore suggests an upgrading of the wastwater treatment plants by including processes such as rapid sand filtration and UV disinfection, which have proved to be effective in the removal and inactivation of pathogenic bacteria and viruses.
\end{abstract}

Keywords: wastewater, chlorination, effluent, pathogenic bacteria

\section{Introduction}

A lack of basic services such as water supply and sanitation is a key symptom of poverty and underdevelopment. The provision of such services must therefore be part of a coherent development strategy if it is to be successful. In developing countries, a large percentage of the population lacks access to safe clean water and sanitation, particularly in Asia and sub-Saharan Africa. This has then been associated with high rates of waterrelated diseases (WHO and UNICEF, 2000).

One of the priorities in the treatment of wastewater is the removal of pathogenic microorganisms in order to comply with the required discharge standards for the treated effluent. In general, the proper implementation of this management strategy results in: the protection of the quality of water sources; the reduction of the cost of drinking water treatment; and the control or prevention/elimination of waterborne diseases. Although wastewater has been treated in certain developing countries, the major aim of producing effluent of a high microbiological quality remains a matter of great concern. In Africa, for example, the 34 million people who have gained access to a sewer connection in the 1990 s represent only $20 \%$ of the new

\footnotetext{
* To whom all correspondence should be addressed.

푱 +2712382 6365; fax: +2712 3826354 ;

e-mail: mombamnb@tut.ac.za

Received 28 May 2010; accepted in revised form 12 October 2010.
}

African population, an estimated 169 million people (WHO and UNICEF, 2000). Despite access to improved sanitation systems, most of these wastewaters collected through the sewer systems are inadequately treated, and discharge significant amounts of faecal pollution indicators and pathogenic microorganisms into the receiving water bodies, leading to a reduction in the quality of the water sources (Bahlaoui et al., 1997, Momba and Mfenyana, 2005). A more serious concern is that these water sources are used by communities for multiple purposes, which include drinking, recreational and agricultural purposes (Toze, 2004; Momba et al., 2006a).

The role of water in the transmission of disease tends to be forgotten in developing countries by consumers and especially by managers of wastewater and drinking water treatment plants. However, waterborne diseases remain an ever-present threat to communities and to everyone relying on direct use of water from rivers without any treatment. Globally, waterrelated causes account for approximately $80 \%$ of all communicable diseases (Wagstaff, 2002). An estimated 1.7 million people in developing countries die annually from diseases linked to unsafe water and sanitation and poor hygiene. Children are the most vulnerable population, as more than 6000 children die every day from diseases associated with unsafe water and inadequate sanitation (WHO and UNICEF, 2000).

In order to assess the effectiveness of a wastewater treatment plant, a monitoring system must be able to determine whether a facility is effectively removing pathogens from the influent. There are specific measuring techniques in place that 
can monitor the microbiological quality of the treated effluent. For routine control purposes, bacterial indicator tests include, for example, faecal coliform tests and especially Escherichia coli. Although most coliforms are harmless to human health, the presence of $E$. coli, which comprises $97 \%$ of coliform bacteria found in the intestines of animals and in faeces, is an indicator that more harmful pathogens are present in the water system (DWAF, 1996).

Monitoring the viral pathogens for routine control purposes is always based on somatic and F-RNA coliphages, due to the fact that these indicators are relatively simple and rapid to detect and easy to characterise in water, and are always present in the faeces of man and warm-blooded animals. Hence they are found in large numbers in sewage (Havelaar et al., 1993).

The present study aimed at assessing the effectiveness of 4 wastewater treatment plants of the Gauteng Province in the removal of pathogenic bacteria and viral indicators. Pathogenic bacteria, such as Salmonella typhimurium, Vibrio cholera and enterotoxigenic Escherichia coli, and viral indicators were targeted because of the important role they play in the transmission of waterborne diseases. Salmonella species are the causative agent of human salmonellosis, which results in enterocolitis, typhoid fever, paratyphoid fever and septicemia (Petit and Wamola, 1994). The diseases can either be symptomatic or asymptomatic. Salmonella spp. are harboured in and transmitted by sewage and other polluted waters (Gopo et al., 1997, Momba et al., 2006a). Vibrio cholerae is the causative agent of cholera, which is one of the classic waterborne diseases. The bacterium is excreted in large numbers in the excreta of the victims suffering with cholera; it likes an alkaline environment and can survive in environmental water bodies for several weeks at the very least (Farmer and HickmanBrenner, 1992). Cholera has been regarded as endemic in South Africa. Between 2000 and 2003, 128468 cases were reported, which resulted in 395 deaths in the country (Hemson and Dube, 2004). Somatic and F-RNA coliphages share similar survival characteristics with enteric viruses when discharged into the aquatic environment (Havelaar et al., 1993). Monitoring the quality of wastewater effluent before the discharge into the receiving water body might therefore assist water services authorities to trace the origin of an epidemic that may occur in the Gauteng Province.

\section{Materials and methods}

\section{Study sites}

The study was conducted at 4 wastewater treatment plants in the vicinity of Pretoria, Gauteng Province. All these plants treat municipal wastewaters using the activated sludge system. The Zeekoegat and Baviaanspoort Water Care Works (WCW) are two of several wastewater treatment plants that serve the City of Tshwane Metropolitan Municipality. Both plants are located approximately $40 \mathrm{~km}$ east of Pretoria (which forms part of the Tshwane municipal area). These 2 plants were studied because they drain into the Roodeplaat Dam, which serves as a source of water for several drinking water treatment plants in the area. It is also a recreational area.

The Zeekoegat WCW is located immediately to the west of the Roodeplaat Dam. This plant has a design capacity of 35 $\mathrm{M} \ell /$ day, which is upgradeable to $120 \mathrm{M} \ell /$ day. At the Zeekoegat WCW, the influent flows into primary settling tanks and then to a division tank that enables the process controllers to maintain a constant flowrate to the 2 biological reactors despite changes in influent flowrates. The biological reactors are characterised by automated submerged diffusion-air aeration systems. The effluent from the biological reactors flows to the secondary settling tanks where clarification takes place. The overflow from the settlers flows through sand filters and finally to an emergency dam where a prolonged contact time with chlorine is achieved. The treated effluent flows into the Roodeplaat Dam via a short earth canal that passes through the Roodeplaat Dam Nature Reserve.

The Baviaanspoort WCW has a capacity of approximately $35 \mathrm{M} \ell /$ day. The set-up of the Baviaanspoort WCW is similar to that of the Zeekoegat WCW. The main difference is in the design of the plant, which is characterised by the lack of a division tank, the presence of a mechanical aeration system in the 2 biological reactors and the absence of sand filtration of the final treated effluent. This plant is located $10 \mathrm{~km}$ upstream of the Roodeplaat Dam on the eastern bank of the Pienaars River.

The Rayton and Refilwe WCWs are located in the small towns of Rayton and Cullinan, respectively, and serve their respective towns. These towns are also approximately $45 \mathrm{~km}$ east of the Pretoria. The populations, according to the Statistics South Africa 2001 census of Cullinan and Rayton, were 7683 and 2 961, respectively (STATSSA, 2001). The design of these plants is simpler than those of the first 2 plants. The influent flows through a grit screen and then into a single biological reactor tank. The effluent of the biological reactor flows to the settling tank and the overflow of the settler flows to the chlorination tank. After the contact tank, no further treatment is done. The effluent is discharged into the receiving water bodies. The design capacities of the Rayton and Refilwe WCWs are 0.6 and $1.1 \mathrm{M} /$ day, respectively. Because of their small size, they were included in this study to compare their performance with that of the larger plants.

\section{Collection of samples}

In order to determine the efficiency of the WWTPs in removing the targeted pathogenic bacteria and viral indicators, samples of the raw influents and the final effluents were aseptically collected. Sample collection was done on a weekly basis between 24 May 2007 and 30 April 2008, in sterile $500 \mathrm{~m} \ell$ glass bottles, for microbial analysis. For the chlorinated final effluents, the sampling was done with the sterile bottles containing approx. $17.5 \mathrm{mg} / \mathrm{m} \ell$ sodium thiosulphate. The samples were then placed in cooler-boxes containing ice packs and transported to the Water Research Group laboratory at the Tshwane University of Technology. The samples were analysed within 4 to 6 hours after collection.

\section{Free chlorine and turbidity analysis}

The concentrations of free chlorine residual in the treated effluent samples were determined on-site using a multi-parameter ion-specific meter (Hanna BDH-laboratory). The turbidity of the final effluent was determined using a portable turbidity meter; model TN-100 (Eutech Instruments).

\section{Culture-based isolation and identification of bacterial enteric pathogens}

The raw influent and final effluent samples were analysed for Escherichia coli, Salmonella spp. and Vibrio spp. using internationally accepted techniques and principles. Briefly, the detection of E. coli was determined by spread plate methods 
using Chomocult coliform agar (Merck,SA) and plates were incubated at $44.5^{\circ} \mathrm{C}$ for $24 \mathrm{~h}$. The isolation of Salmonella was done by enrichment in tetrathionate broth (Merck) in accordance with the established method (APHA, 1998). The isolation of the Vibrio spp. was done by enrichment in alkaline peptone broth ( $\mathrm{pH} \mathrm{8.5)} \mathrm{for} 6$ to $8 \mathrm{~h}$ at $37^{\circ} \mathrm{C}$, after which the cultures were diluted and plated, mostly on thiosulphate citrate bile salts sucrose (TCBS) (Merck, SA) agar (APHA, 1998; SABS, 2001).

Following enumeration, 3 characteristic colonies, Escherichia coli, Salmonella spp. and Vibrio spp., were selected and sub-cultured 3 times on the selective media prior to identification. The Gram stain procedure was then performed and the oxidase test was carried out on the Gram-negative isolates. The API 20E kit was used for the oxidase-negative colonies. The strips were then read and the final identification was secured using API LAB PLUS computer software (BioMérieux, Marcy l'Etoile, France).

\section{Molecular confirmation of pathogenic bacterial isolates}

\section{Bacterial strains}

Pathogenic Escherichia coli ATCC 25922 and Salmonella typhimurium ATCC 14028 were obtained from the American Type Culture Collection, Rockville, MD, USA. Vibrio cholerae NCTC 5941 was obtained from the National Collection of Type Cultures, London, UK. These strains were reconfirmed by cultural, morphological and biochemical tests according to standard procedures and were used as reference strains.

\section{DNA extraction and preparation of the lysates for PCR}

The polymerase chain reaction was used to confirm the identities of the presumptive pathogenic bacteria isolated. The DNA extraction was performed using the DNA FastDNA kit according to the manufacturers' instructions (Q-Biogene, Carlsbad, Calif, USA). The oligonucleotide primers and targeted genes for each pathogen are shown in Table 1.

\section{Oligonucleotide primers}

Oligonucleotide primers (Table 1), specific for the uidA gene of $E$. coli encoding for $\beta$-D-glucuronidase, the ipaB gene of $S$. typhimurium encoding the invasion plasmid antigen $\mathrm{B}$ and the epsM gene of $V$. cholerae encoding the enterotoxin extracellular secretion protein of toxigenic $V$. cholerae, were used, as they have been reported to be specific for the respective bacteria (Kong et al., 2002, Momba et al., 2006b).

\section{PCR amplification and electrophoretic detection of amplicons}

The PCR reaction was carried out in $50 \mu \ell$ reaction volume containing $10 \times$ GOLD Buffer, $1.5 \mathrm{mM} \mathrm{MgCl}$, each of the 4 deoxynucleotides (dNTPs) (Promega, Whitesci SA) at a concentration of $0.25 \mathrm{mM}, 100 \mathrm{pmol}$ for each primer stated in Table 1, and $5 \mathrm{U}$ of Go-taq DNA polymerase (Promega, Whitesci SA). A total volume of $10 \mu \ell$ genomic DNA was used in each PCR reaction. The reaction was carried out in a BioRad Chromo 4 Cyler (Bio-Rad, SA). The following reaction conditions, optimised from Momba et al. (2006b), were used: initial denaturation at $94^{\circ} \mathrm{C}$ for $2 \mathrm{~min}$ followed by reaction cycles (25 cycles for E. coli and Vibrio sp. and 35 cycles for Salmonella spp.), denaturation at $94^{\circ} \mathrm{C}$ for $1 \mathrm{~min}$ for all reactions, annealling at $58^{\circ} \mathrm{C}$ for $1 \mathrm{~min}$ for E. coli and Vibrio spp. and $62^{\circ} \mathrm{C}$ for $1 \mathrm{~min}$ for Salmonella spp., and extension at $72^{\circ} \mathrm{C}$ for $2.5 \mathrm{~min}$. The final extension cycle was followed by incubation at $72^{\circ} \mathrm{C}$ for $10 \mathrm{~min}$ and cooling at $4{ }^{\circ} \mathrm{C}$.

The amplicons ( $10 \mu \ell$ aliquots) were visualized on a $2 \%$ $(\mathrm{w} / \mathrm{v})$ agarose gel (Merck) in $1 \mathrm{U}$ TAE buffer (40 mM Tris- $\mathrm{HCl}$, 20mM Na-acetate, $1 \mathrm{mM}$ EDTA, $\mathrm{pH}$ 8.5) and stained with $0.5 \mu \mathrm{g} / \mathrm{m} \ell$ ethidium bromide (EtBr, Merck). The amplified products were viewed under the Syngene Gel-Doc System. A 100-bp ladder (Promega, Whitesci SA) was included on each gel as a molecular size standard. The electrophoresis was carried out at $76 \mathrm{~V}$ for $50 \mathrm{~min}$.

\section{Culture-based isolation of somatic and F-RNA coliphages}

For the coliphage analyses, wastewater samples were passed through filters ( $25 \mathrm{~mm}, 0.45 \mu \mathrm{m}$ Millipore filters) into sterile $250 \mathrm{~m} \ell$ flasks. Prior to use, the filters were pre-treated with 10 $\mathrm{m} \ell$ of sterile $1.5 \%$ beef extract to minimise phage adsorption to the filters. The filtrates were then serially diluted in antibioticfree peptone-saline within the range of $10^{-1}$ to $10^{-3}$. Enumeration of somatic coliphages and F-RNA coliphages was done on double-agar-layer plaque assay using E. coli strain C (ATCC 13706) nalidixic acid-resistant mutant WG5 and Salmonella typhimurium WG 49 nalidixic acid-resistant mutant as hosts, respectively, and inoculum culture was prepared as described elsewhere (SANS, 2002).

\section{Statistical analysis}

To show the efficiency of the 4 plants for the removal of pathogenic bacteria and viral indicators, the data were analysed statistically using the SPSS computer software, Version 11.0. Comparison of means was done using the one-way analysis of variance (ANOVA) and test of relationship was carried out using the Pearson correlation index at a $95 \%$ confidence interval.

Table 1

PCR primer base sequences and targeted amplicon size of pathogenic bacterial isolates

\begin{tabular}{|c|c|c|c|c|c|}
\hline Target organism & Primer set & Primer sequence (5'-3') & Targeted gene fragment & $\begin{array}{l}\text { PCR } \\
\text { Amplicon }\end{array}$ & Reference \\
\hline \multirow{2}{*}{ E. coli } & & & \multirow{2}{*}{$\beta$-D-glucuronidase gene (uidA) } & \multirow{2}{*}{$147 \mathrm{bp}$} & \multirow{2}{*}{$\begin{array}{l}\text { Tsai et al. } \\
\text { (1993) }\end{array}$} \\
\hline & UAR-754 & AAA ACG GCA & & & \\
\hline \multirow{2}{*}{ S. typhimurium } & IpaB-F & GGA & \multirow{2}{*}{ Inversion plasmid B (IpaB) } & \multirow{2}{*}{$314 \mathrm{bp}$} & \multirow{2}{*}{$\begin{array}{l}\text { Kong et al. } \\
(2002)\end{array}$} \\
\hline & IpaF-R & GCC & & & \\
\hline \multirow{2}{*}{ V. cholerae } & EspM-F & GAA TTA TTG GCT CCT GTG CAG G & \multirow{2}{*}{$\begin{array}{l}\text { Enterotoxin extracellular secre- } \\
\text { tion protein } \mathrm{M} \text { gene }(E s p M)\end{array}$} & \multirow{2}{*}{$248 \mathrm{bp}$} & \multirow{2}{*}{$\begin{array}{l}\text { Kong et al. } \\
(2002)\end{array}$} \\
\hline & \begin{tabular}{|l|} 
EspM-R \\
\end{tabular} & ATC GCT TGG CGC ATC ACT GCC C & & & \\
\hline
\end{tabular}



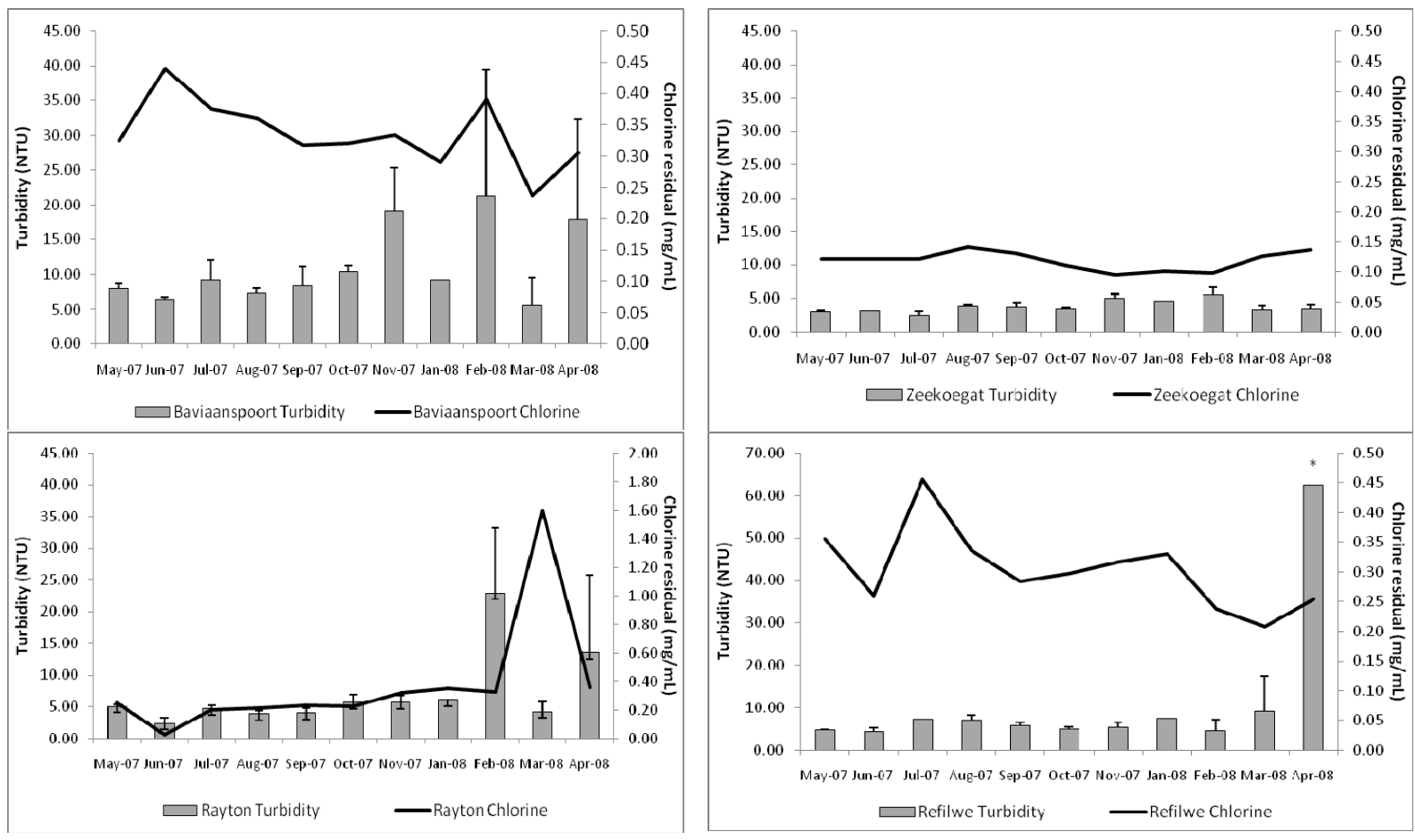

Figure 1

Average concentration of free chlorine residual and turbidity in the final effluent in the 4 plants

\section{Results}

\section{Concentration of chlorine residual and turbidity in the final effluents}

The free chlorine residual concentrations and the turbidity in the final effluents of the wastewater treatment plants for each month during the study period are represented in Fig. 1. The concentration of free chlorine residual ranged from 0.09 to $0.14 \mathrm{mg} / \ell$ in Zeekoegat effluents, from 0.24 to $0.44 \mathrm{mg} / \ell$ in Baviaanspoort effluents, from 0.03 to $1.60 \mathrm{mg} / \ell$ in Rayton effluents, and from 0.21 to $0.46 \mathrm{mg} / \ell$ in Refilwe effluents. The highest concentrations of free chlorine residual were observed in the months of August, June, March and July, for the Zeekoegat, Baviaanspoort, Rayton and Refilwe WCWs, respectively (Fig. 1). Also, the lowest chlorine concentrations were observed in the months of November (for Zeekoegat), March (for Baviaanspoort), June (for Rayton) and March (for Refilwe). Although the residual chlorine concentrations in the different WCWs were observed to differ throughout the period of sampling, these differences were not observed to be significant within each plant. However, the free chlorine residual concentrations in the Zeekoegat WCW were observed to be significantly lower compared to those recorded in the Refilwe WCW $(p \leq 0.05)$.

The turbidity of the effluents ranged from 2.45 to 5.52 NTU, from 5.62 to $21.24 \mathrm{NTU}$, from 2.39 to $22.92 \mathrm{NTU}$, and from 4.36 to $62.40 \mathrm{NTU}$, in the Zeekoegat, Baviaanspoort, Rayton and Refilwe WCWs, respectively (Fig. 1). Although the different WCWs were observed to differ in turbidity ranges throughout the period of sampling, these differences were not observed to be significant in each and every plant. Significant differences in free chlorine concentrations were noted only when the Zeekoegat WCW was compared to the rest of the plants $(p \leq 0.05)$.

\section{Influent and effluent loads of pathogenic bacteria as detected by conventional methods}

Figure 2 shows the counts of $E$. coli isolated from the influent samples of the 4 plants during the study period. These counts ranged from 4.57 to $5.08 \log _{10} \mathrm{CFU} / \mathrm{m} \ell$, from 3.56 to $5.56 \log _{10}$ $\mathrm{CFU} / \mathrm{m} \ell$, from 4.26 to $4.86 \log _{10} \mathrm{CFU} / \mathrm{m} \ell$, and from 4.52 to $5.72 \log _{10} \mathrm{CFU} / \mathrm{m} \ell$ in the Zeekoegat, Baviaanspoort, Rayton and Refilwe WCWs, respectively. Escherichia coli counts in the Baviaanspoort WCW were observed to be significantly higher than those of Refilwe and Rayton WCWs $(p \leq 0.05)$. Also, influent counts from the Zeekoegat WCW were observed to be significantly higher than those from the Rayton WCW $(p \leq 0.05)$.

Figure 3 shows the counts of E. coli isolated from the effluent samples in the 4 plants during the study period. These counts ranged from 0.00 to $0.70 \log _{10} \mathrm{CFU} / \mathrm{m} \ell$, from 1.24 to $4.95 \log _{10} \mathrm{CFU} / \mathrm{m} \ell$, from 0.00 to $4.77 \log _{10} \mathrm{CFU} /$ $\mathrm{m} \ell$, and from 1.89 to $4.80 \log _{10} \mathrm{CFU} / \mathrm{m} \ell$ in the Zeekoegat, Baviaanspoort, Rayton and Refilwe WCWs, respectively. The highest faecal coliform removal was observed in the Zeekoegat WCW and the lowest in the Refilwe WCW (Fig. 3). The effluent counts were observed to be significantly different in the 4 plants throughout the period of sampling $(p \leq 0.05)$. However, the counts in the Baviaanspoort WCW were observed to not be significantly higher than those of the Rayton WCW $(p>0.05)$.

Table 2 shows the occurrences of the 3 target pathogenic bacteria in the influents and effluents of the 4 wastewater plants after biochemical identification and molecular identification. During the study period, presumptive $E$. coli was present in all 32 effluent samples collected from Baviaanspoort WCW. A similar occurrence of approximately $90 \%$ was found in Rayton and Refilwe WCWs, while a lower occurrence of $9 \%$ was noted in the 


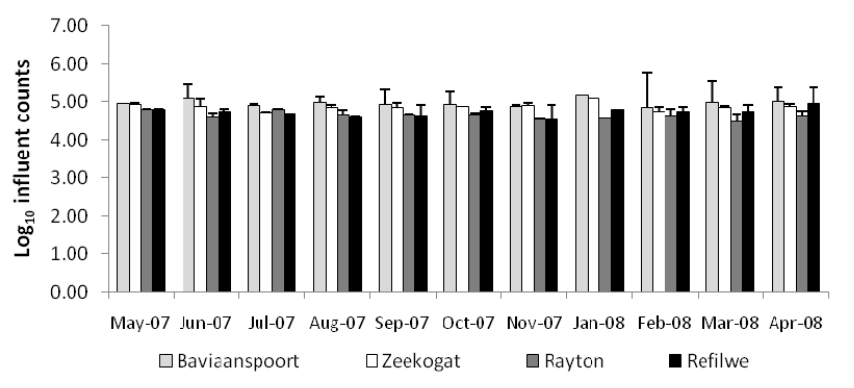

Figure 2

Presumptive E. coli counts from the influent of the 4 wastewater treatment plants. The graphs show a plot of the monthly average of $\log _{10} \mathrm{CFU} / \mathrm{ml}$ for pathogenic bacteria over the period of the study, May 2007-April 2008.

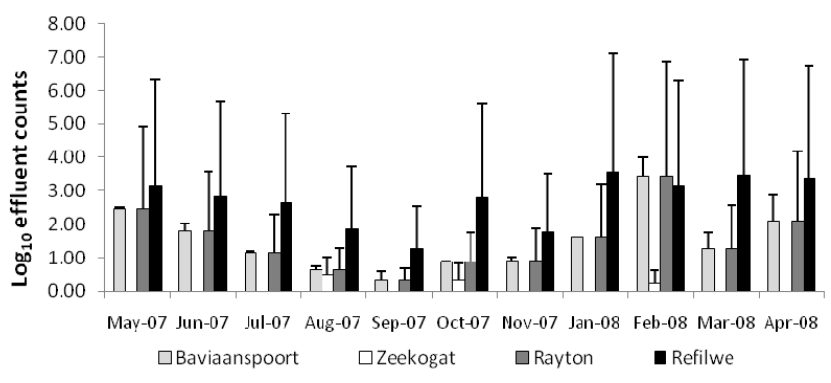

Figure 3

Presumptive E. coli counts isolated from the effluent of the 4 wastewater treatment plants. The graphs show a plot of the monthly average of $\log _{10} \mathrm{CFU} / \mathrm{ml}$ for pathogenic bacteria over the period of the study, May 2007-April 2008.

\begin{tabular}{|c|c|c|c|c|}
\hline \multicolumn{5}{|c|}{ Table 2} \\
\hline \multicolumn{5}{|c|}{$\begin{array}{l}\text { Occurrence of E. coli, Salmonella and Vibrio species in effluents of the } 4 \text { wastewater } \\
\text { treatment plants }(n=32 \text {, May } 2007 \text { and April 2009) }\end{array}$} \\
\hline \multicolumn{5}{|c|}{ Number of effluent samples contaminated by presumptive bacteria using culture-based methods } \\
\hline Organism & Baviaanspoort & Zeekoegat & Rayton & Refilwe \\
\hline E. coli & $100 \%$ & $9.4 \%$ & $90.6 \%$ & $90.6 \%$ \\
\hline Salmonella spp. & $90.6 \%$ & $0 \%$ & $56.3 \%$ & $71.9 \%$ \\
\hline Vibrio spp. & $59.4 \%$ & $0 \%$ & $25.0 \%$ & $68.8 \%$ \\
\hline \multicolumn{5}{|c|}{ Number of effluent samples confirmed positive for E. coli, S. typhimurium and V. cholerae using PCR } \\
\hline Organism & Baviaanspoort & Zeekoegat & Rayton & Refilwe \\
\hline E. coli & $32 / 32(100 \%)$ & $3 / 32(8.8 \%)$ & $24 / 32(75 \%)$ & $28 / 32(87.5 \%)$ \\
\hline S. typhimurium & $29 / 32(88.2 \%)$ & $0 / 32(0 \%)$ & $13 / 32(38.2 \%)$ & $19 / 32(59.4 \%)$ \\
\hline V. cholerae & $12 / 32(35.3 \%)$ & $0 / 32(0 \%)$ & $3 / 32(9.4 \%)$ & $7 / 32(21.9 \%)$ \\
\hline
\end{tabular}

\begin{tabular}{|c|c|c|c|c|c|c|}
\hline \multicolumn{7}{|c|}{$\begin{array}{c}\text { Table } 3 \\
\text { Performance of WCWs to remove coliphages from wastewater influents- Average } \text { Log }_{10} \text { counts and } \\
\text { coliphage removal percentages in each of the WCWs }(n=32 \text {, May } 2007 \text { to April 2008) }\end{array}$} \\
\hline \multirow[t]{2}{*}{ Plant (WCW) } & \multicolumn{3}{|c|}{ Somatic } & \multicolumn{3}{|c|}{ FRNA } \\
\hline & $\begin{array}{c}\text { Influent } \\
\text { PFU/100me (sd) }\end{array}$ & $\begin{array}{c}\text { Effluent } \\
\text { PFU100/me(sd) }\end{array}$ & $\begin{array}{c}\% \\
\text { Removal }\end{array}$ & $\begin{array}{c}\text { Influent } \\
\text { PFU100/me (sd) }\end{array}$ & $\begin{array}{c}\text { Effluent } \\
\text { PFU/100m }(\mathrm{sd})\end{array}$ & $\begin{array}{c}\% \\
\text { Removal }\end{array}$ \\
\hline Baviaanspoort & $5.78(0.336)$ & $4.92(0.412)$ & 15.57 & $5.23(0.348)$ & $4.50(0.506)$ & 13.96 \\
\hline Zeekoegat & $5.79(0.121)$ & $3.45(0.338)$ & 40.41 & $5.66(0.109)$ & $2.69(1.190)$ & 52.47 \\
\hline Rayton & $5.62(0.134)$ & $4.19(1.017)$ & 25.76 & $5.39(0.247)$ & $3.66(1.413)$ & 32.10 \\
\hline Refilwe & $5.79(0.208)$ & $5.12(0.384)$ & 11.62 & $5.71(0.242)$ & $4.43(0.679)$ & 22.42 \\
\hline
\end{tabular}

effluents collected from the Zeekoegat WCW. With the exception of this plant, Salmonella and Vibrio spp. occurred in the effluents collected from all the plants. In these plants, the highest occurrences of these organisms were observed in the Baviaanspoort WCW $(90.6 \%$ for Salmonella) and in the Refilwe WCW (68.8\% for Vibrio spp.) (Table 2).

\section{Molecular confirmation of the pathogenic bacteria isolates with PCR}

While the PCR analysis confirmed the absence of the target species of Salmonella and Vibrio in effluents collected from the Zeekoegat WCW, and the occurrence of pathogenic E. coli at a lower rate of $9.4 \%$, the 3 bacterial pathogens effectively occurred at high rates in the remaining plants. Pathogenic E. coli was positively confirmed in all the effluents collected from the Baviaanspoort WCW. Salmonella typhimurium (88.2\%) and $V$. cholerae $(35.3 \%)$ were found at high occurrence rates in this plant compared to the Refilwe and Rayton WCWs (Table 2).

\section{Influent and effluent loads of somatic and F-RNA coliphages as detected by conventional methods}

The average counts of somatic and F-RNA coliphages in the influents of all plants were found to be $5.75 \log _{10} \mathrm{PFU} / \mathrm{m} \ell$ and $5.50 \log _{10} \mathrm{PFU} / \mathrm{m} \ell$, respectively. As shown in Fig. 4, the counts of F-RNA coliphage were found to be lower than those of the somatic coliphages in the effluents of all plants. These counts ranged from 0.00 to 5.88 and 0.00 to $5.80 \log _{10} \mathrm{PFU} / \mathrm{m} \ell$, respectively. A significant removal of both somatic and F-RNA coliphages was observed for all plants $(p \leq 0.05)$.

With reference to Table 3, the highest reductions of viral indicators, of $40 \%$ and $53 \%$, were observed in the Zeekoegat WCW for somatic and F-RNA coliphages, respectively. In this plant, reductions of up to 3.40 and $2.69 \log _{10} \mathrm{PFU} / \mathrm{m} \ell$ were observed in the effluent for somatic and F-RNA coliphages, respectively. The lowest removal efficiency $(12 \%)$ of somatic coliphages was observed in the Refilwe WCW, with a reduction from an average influent count of $5.79 \log _{10} \mathrm{PFU} / \mathrm{m} \ell$ to $5.12 \log _{10} \mathrm{PFU} / \mathrm{m} \ell$ in its final effluents. Baviaanspoort WCW showed the lowest removal of F-RNA coliphages, of $14 \%$, from 

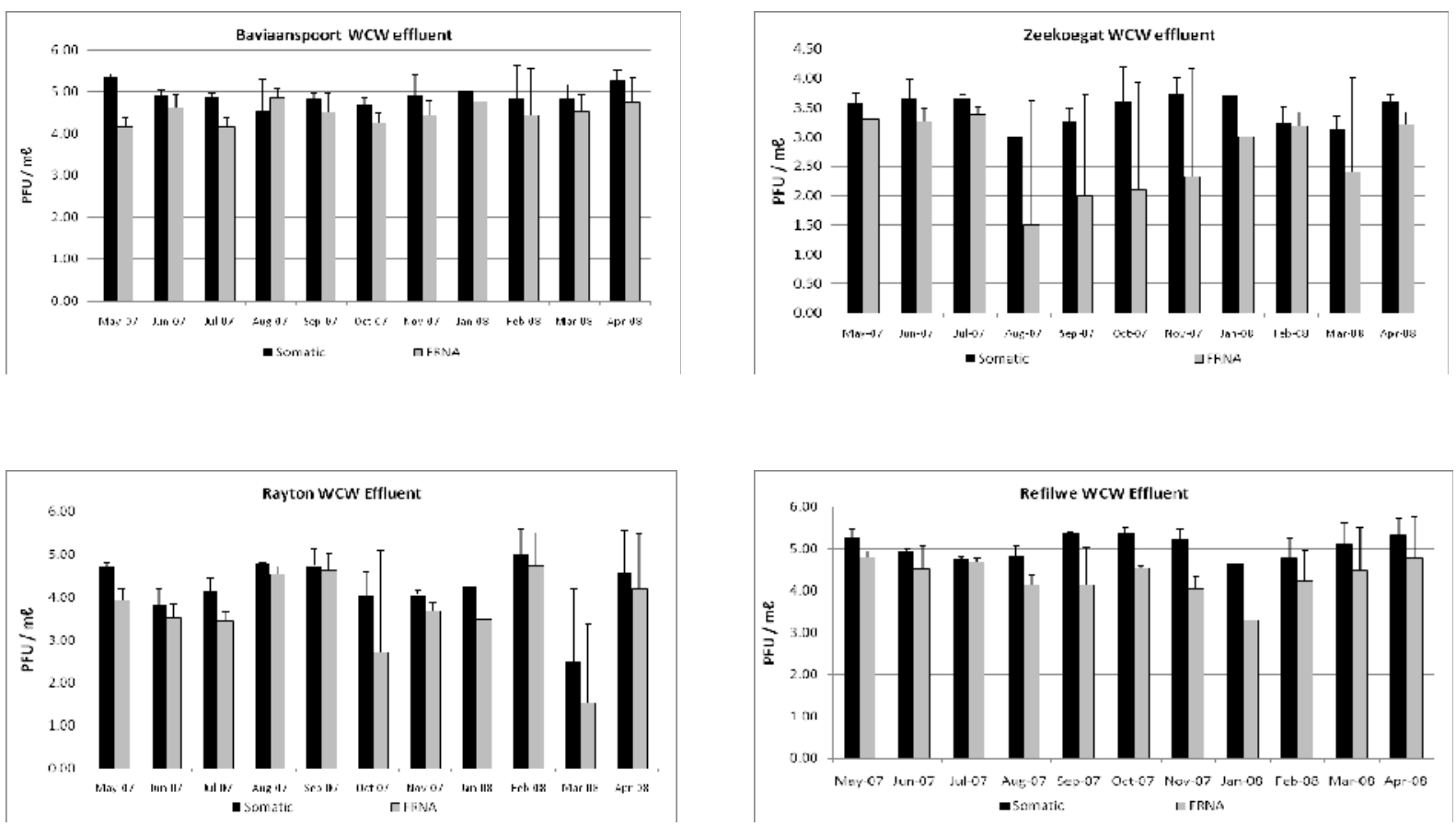

Figure 4

Performance of the different wastewater treatment plants for the removal of the somatic and F-RNA coliphages during the study period between May 2007 and April 2008

an average influent count of $5.23 \log _{10} \mathrm{PFU} / \mathrm{m} \ell$ to an average effluent count of $4.50 \log _{10} \mathrm{PFU} / \mathrm{m} \ell$.

\section{Discussion}

There is an increasing trend of requiring more efficient use of water resources, both in urban and rural environments. Recycled water can have the advantage of being a constant, reliable water source and of reducing the amount of water extracted from the environment. As South Africa is a waterscarce country, return flows (sewage and effluent purification) occupy second position in terms of their contribution to the country's freshwater supply, with $14 \%$ of the total water supply deriving from this source, while $77 \%$ is sourced from surface water (dams and rivers) and 9\% from groundwater (boreholes) (Van Vuuren, 2009). By law (National Water Act, No. 36 of 1998), all treated effluent is required to flow back into public streams or into the sea (DWAF, 2004). The last step in the wastewater treatment process before the effluent is returned to the public stream is disinfection. Disinfection of wastewater is carried out for the partial destruction of disease-causing organisms. Factors such as the concentration of disinfectant, contact time and nature of suspending liquid influence the action of disinfectants such as chlorine and UV radiation (Metcalf and Eddy, 2003), hence the necessity of measuring the concentration of free chlorine residual and the turbidity of the final effluents of the 4 plants.

At present, wastewater effluent disinfection practices are dominated by using liquid-gas chlorine $\left(\mathrm{Cl}_{2}\right)$ or chlorine compounds. The effluents to be discharged from wastewater treatment plants to the water resources (such as rivers) at the final monitoring point must always comply with the general limit of $0.25 \mathrm{mg} / \ell$ of free chlorine residual or the relaxed-limit of $0.1 \mathrm{mg} / \ell$. These concentrations result in the inactivation of faecal coliforms to the prescribed standard of zero CFU/100 $\mathrm{m} \ell$ of the effluent or at a special limit of $1000 \mathrm{CFU} / 100 \mathrm{~m} \ell$ effluent (DWAF 2004). It is well known that $E$. coli is considered as a representative of the faecal coliform group that is primarily used to indicate the presence of bacterial pathogens such as Salmonella spp., Shigella spp., V. cholerae, Campylobacter jejuni, Campylobacter coli, Yersinia enterocolitica and pathogenic E. coli (DWAF, 1996). This means that the prescribed free chlorine residual limits should also result in the inactivation of E. coli, V. cholerae and Salmonella typhimurium, which were the target organisms in this investigation.

Despite significant removals of pathogenic bacteria in all 4 plants, only the E. coli counts from Zeekoegat WCW showed significant compliance with the current standard, with respect to the reduction of the faecal coliforms at the special limit set by the South African Water Services Authority (DWAF, 2004) (Fig. 3). The occurrence of this coliform group in the chlorinated effluent of the Baviaanspoort WCW was observed to be significantly higher than at other plants $(p \leq 0.05)$. This study demonstrated that chlorine disinfection of wastewater effluents could not produce effluent which complied with the prescribed bacterial standards.

Bacterial pathogens such as E. coli, V. cholera and Salmonella typhimurium are among the major health risks associated with water in general and wastewater in particular. Their detection by using culture-based methods alone tends to be inaccurate at a species-specific level, as percentages obtained using PCR are all lower than those obtained using culture-based methods (Table 2), indicating that molecular identification provides more information pertaining to the proportion of specific pathogenic species and the actual quality of water (Momba et al., 2006b). There is therefore a need for a molecular confirmation of the presumptive isolates obtained from conventional methods. The results obtained from this study using both the culture-based methods and the PCR species-specific techniques indicated a remarkable reduction in 
the occurrence of E. coli and a complete removal of $V$. cholera and Salmonella typhimurium only from the effluents produced in the Zeekoegat WCW, which maintained a low average free chlorine residual concentration of $0.12 \mathrm{mg} / \ell$ (Table 2 and Fig. 1). However, the Baviaanspoort, Rayton and Refilwe WCWs, which maintained high free chlorine residual concentrations, produced poor effluents with high occurrence rates of the 3 target pathogenic bacteria (Table 2, Fig. 1). Lower turbidity levels due to the incorporation of a rapid sand filtration process in the Zeekoegat WCW, coupled with longer contact times in the emergency dam, contributed to the reduction of E. coli (Figs. 2 to 3 ) and the total removal of pathogenic E. coli, V. cholerae and $S$. typhimurium compared to other plants (Table 2). On the other hand, the lack of the rapid sand filtration process resulted in higher turbidity levels in the Baviaanspoort, Rayton and Refilwe WCWs, and therefore reduced the effectiveness of chlorine by shielding the entrapped bacteria (Table 2, Figs. 2 and 3). Athough these 3 plants experienced larger influent loadings than their design capacities, the Baviaanspoort WCW had significantly larger influent loads of $E$. coli compared to the Rayton and Refilwe WCWs $(p \leq 0.05)$. In a study conducted by Gaydon and co-workers (2006), when evaluating package plants and larger plants for community use, these authors concluded that, although overloading might occur, larger plants, due to their size, are generally better equipped to deal with varying loading rates. Unfortunately, this was not noted in the case of the Baviaanspoort WCW, which has a design capacity of approximately $35 \mathrm{M} /$ /day compared to the Rayton and Refilwe WCWs, which have design capacities of 0.6 and $1.1 \mathrm{M} \ell /$ day, respectively.

The failure of South African wastewater treatment plants to produce final effluents of a high bacteriological quality when using chlorine disinfection has been previously reported. Pretorius and Pretorius (1999) found that, across the country, only $33 \%$ of the total effluents flowing from all of the wastewater works to the receiving water bodies met bacteriological standards of nil faecal coliform count $/ 100 \mathrm{~m} \ell$, when using chlorine disinfection. In another study by Samie and coworkers (2009), common pathogenic bacteria, which included Salmonella spp., Shigella spp., Escherichia coli, Vibrio spp. and Enterococcus spp., were isolated from the chlorinated effluents produced by 14 sewage treatment plants in the Mpumalanga Province. Etinosa and coworkers (2009) recently reported the occurrence of potential pathogenic Vibrio spp. in final effluents of a wastewater facility in a rural community of the Eastern Cape Province.

The overall viral qualities of all the effluents produced by the Zeekoegat, Baviaanspoort, Rayton and Refilwe WCWs were above the recommended limits, which are $0-1 \mathrm{PFU} / \mathrm{m} \ell$ for negligible risk for domestic water use and $0-20 \mathrm{PFU} / 100 \mathrm{~m} \ell$ for recreational water use (DWAF, 1996). However, the capability of these plants to remove viral indicators from the influents depended on the treatment process units incorporated in the plants, as also noted in the case of pathogenic bacteria. Lower virus loads were then noted in the effluents of the Zeekoegat WCW than in those of the Baviaanspoort, Rayton and Refilwe WCWs (Fig. 4). Even though the plants had the prescribed free chlorine residual concentration limits, it is important to know that the inactivation of somatic and F-RNA coliphages is dosedependent rather than disinfectant-residual dependent (Tree et al., 2003). Moreover, somatic coliphages have been reported to be resistant to normal operational disinfection levels (Donnison and Ross, 1995). This clearly explains the higher viral removal efficiency noted in the Zeekoegat WCW than in the other
3 plants. As the Refilwe and Rayton WCWs were operating above their normal capacities of approximately 1.1 and $2.3 \mathrm{M} \ell /$ day, the carryover of sludge from the clairifier to the contact tank was frequently observed. Hence, lower removal efficiencies in terms of coliphages were recorded in these plants (Fig.4). The present study corresponds with results obtained in a study conducted by Momba and co-workers (2009) in the Eastern Cape Province, where none of the wastewater treatment plants were efficient in removing coliphages up to the acceptable standards.

The study also revealed a significant correlation between pathogenic bacteria, somatic and F-RNA coliphage removal in all plants $(r=0.765$ for Baviaanspoort WCW; $r=0.904$ for Zeekoegat WCW; $r=0.680$ for Refilwe WCW; $r=0.796$ for Rayton WCW, $p<0.01$ ). Our results showed that sewagerelated microorganisms had different sensitivities to the treatment and also that these patterns of sensitivity were not dependent on the free chlorine concentrations in the plants. For an efficient disinfection process to result in the removal of pathogenic bacteria and coliphages, low turbidity should be ensured (Tree et al., 2003).

The presence of pathogenic E. coli, S. typhimurium, Vibrio cholerae and viral indicators in treated wastewater effluent is a potential public health hazard, as this water source is directly discharged in receiving water bodies and may be used by communities for multiple purposes. The poor quality of water sources in South Africa has been linked to effluents discharged into the catchment by the wastewater treatment plants, informal residential areas upstream of the study site and agricultural activities (Momba et al., 2006a; Oberholster et al., 2008; Samie et al., 2009; Igbinosa and Okoh, 2009), Momba et al., 2009). Inadequate treatment of wastewater effluents is undermining efforts to end waterborne diseases in the country. There is therefore a great need to adopt a new approach in wastewater treatment processes and to ensure the proper management of wastewater treatment plants in all the provinces, in order to produce effluents that comply with the current standards.

\section{Conclusions and recommendations}

The low counts for targeted pathogenic bacteria and viral indicators observed in the effluents of the Zeekoegat WCW highlight the importance of long contact times coupled with clear (low turbidity) effluents. The presence of a filtration process and a contact dam are the main reasons why this activated sludge system had a higher removal efficiency of targeted pathogenic bacteria and viral indicators than the other systems evaluated. A combination of both bacterial and bacteriophage indicators seem to be the best choice for ensuring the microbial quality of wastewater effluents. The results of this study therefore suggest the introduction of a secondary treatment process such as filtration, or a much more efficient disinfection process, in order to improve the performance of the wastewater treatment plants in terms of bacterial and viral removal.

\section{Acknowledgements}

The authors would like to thank the National Research Foundation (NRF) and the Tshwane University of Technology for the funding of this project.

\section{References}

APHA (1998) Standard Methods for the Examination of Water and 
Wastewater (20th edn.) American Public Health Association/ American Water Works Association/Water Environment Federation, Washington, DC

BAHLAOUI MA, BALEUX B, TROUSSELLIER M (1997) Dynamics of pollution-indicator and pathogenic bacteria in high-rate oxidation wastewater treatment ponds. Water Res. 31 630-638.

DONNISON AM and ROSS CM (1995) Somatic and F-specific coliphages in New Zealand wastewater treatment lagoons. Water Res. 29 1105-1110.

DWAF (DEPARTMENT OF WATER AFFAIRS and FORESTRY SOUTH AFRICA) (1996) South African Water Quality Guidelines (2nd edn.) Vol. 2: Domestic Use. Department of Water Affairs and Forestry, Pretoria, South Africa.

DWAF (2004) Revision of general authorization in terms of section 39 of the National Water Act, 1998 (Act No. 36 of 1998). South African Government Gazette No. 26187.

FARMER JJ $3^{\text {RD }}$ and HICKMAN-BRENNER FW (1992) Vibrio and photobacterium. In: Balows A, Truper H, Dworkin M, Harder W and Shleifer K (eds.) The Protokaryotes (2nd edn.) Springer-Verlag, Berlin. 2952-3011.

GAYDON P, MCNAB N, MULDER G, PILLAY L, SAHIBDEEN $M$ and THOMPSON P (2007) Evaluation of Sewage Treatment Package Plants for Rural, Peri-Urban and Community Use. WRC Report No. 1539/1/06.

GOPO JM and BANDA GN (1997) Occurrence of Salmonella on meat and products in an ostrich abattoir as determined with a DNA probe. S. Afr. J. Anim. Sci. 27 (1) 1-6.

HAVELAAR AH, FARRAH SR, JOFRE J, MARQUES E, KETRATANAKUL A, MARTINS MT, OHGAKI S, SOBSEY MD and ZAISS U (1991) Bacteriophages as model viruses in water quality control. Water Res. 25 529-545.

HEMSON D and DUBE B (2004) Water services and public health: the 2000-01 cholera outbreak in KwaZulu-Natal. 8th World Congress on Environmental Health, 22-27 February 2004, Durban, South Africa.

IGBINOSA EO and OKOH AI (2009) Impact of discharge wastewater effluents on the physic-chemical qualities of a receiving watershed in a typical rural community. Int. J. Environ. Sci. Technol. 6 175-182.

KONG RYC, LEE SKY, LAW TWF, LAW SHW and WU RSS (2002) Rapid detection of six types of bacterial pathogens in marine waters by multiplex PCR. Water Res. 36 2802-2812.

METCALF and EDDY (2003) Wastewater Engineering Treatment and Reuse ( $4^{\text {th }}$ edn.). The McGraw Hill Companies Inc., New York

MOMBA MNB and MFENYANA C (2005) Inadequate treatment of wastewater: A source of coliform bacteria in receiving surface water bodies in developing countries - Case study: Eastern Cape Province of South Africa. In: Lehr JH and Keeley J (eds.) Water Encyclopaedia Domestic, Municipality and
Industrial Water Supply and Waste Disposal. A.J. Wiley and Sons Inc., New Jersey. 661-667.

MOMBA MNB, OSODE AN and SIBEWU M (2006a) The impact of inadequate wastewater treatment on the receiving water bodies - Case study: Buffalo City and Nkonkobe Municipalities of the Eastern Cape. Water SA 32 (5) 687-692.

MOMBA MNB, MALAKATE VK and THERON J (2006) Abundance of pathogenic Escherichia coli, Salmonella typhimurium and Vibrio cholerae in Nkonkobe drinking water sources. J. Water Health 4 289-296.

PRETORIUS PC and PRETORIUS WA (1999) Disinfection of purified sewage effluent with monochloramine. Water SA 25 (4) 463-472.

OBERHOLSTER PJ, BOTHA AM and CLOETE TE (2008) Biological and chemical evaluation of sewage water pollution in the Rietvlei Nature Reserve wetland area, South Africa. Environ. Pollut. 156 (1) $184-192$

PETIT PL and WAMOLA IA (1994) Typhoid fever: A review of its impact and diagnostic problems. East Afr. Med. J. 71 183-188.

SABS (2001) Water Quality - Detection and Enumeration of Vibrio cholera (1st edn.). South African Bureau of Standards. Pretoria. South Africa.

SAMIE A, OBI CL, IGUMBOR JO and MOMBA MNB (2009) Focus on 14 sewage treatment plants in the Mpumalanga Province, South Africa in order to gauge the efficiency of wastewater treatment. Afr. J. Biotechnol. 8 (14) 3276-3285.

SOUTH AFRICA NATIONAL STANDARD (SANS) (2002) Water quality - Detection and enumeration of bacteriophages. Part 1: Enumeration of F-specific RNA bacteriophages. SANS 107051:2002 Edn. 1, ISO 10705-1: 1995 Edn. 1. Standards South Africa, Pretoria, South Africa. ISBN: 0-626-13975-9

SOUTH AFRICA NATIONAL STANDARD (SANS) (2002) Water quality - Detection and enumeration of bacteriophages. Part 2: Enumeration of somatic coliphages. SANS 10705-2:2002 Edn. 1, ISO 10705-2: 2000 Edn. 1. Standards South Africa. Pretoria, South Africa. ISBN 0-626-13974-0.

TOZE S (2004) Reuse of effluent water-benefits and risks. In: 'New direction for a diverse planet'. Proc. $4^{\text {th }}$ International Crop Science Congress, 26 September - 1 October 2004, Brisbane, Australia.

TSAI YL, PALMER CJ and SANGERMANO LR (1993) Detection of Escherichia coli in sewage and sludge by polymerase chain reaction. Appl. Environ. Microbiol. 59 353-357.

TREE JA, ADAMS MR AND LEES DN (2003) Chlorination of indicator bacteria and viruses in primary sewage effluent. Appl. Environ. Microbiol. 69 (4) 2038-2043.

WAGSTAFF A (2002) Poverty and health sector inequalities. Bull. World Health Organization 80 (2) 97-105.

WHO and UNICEF (2000) Global Water Supply and Sanitation Assessment 2000 Report. 1-87. URL: http://www.who.int/ water sanitation health/monitoring/globalassess/en/index.html (Accessed 5 October 2006). 